\title{
Evaluation of Detached Leaf Assay for Assessing Leaf Rust (Puccinia triticina Eriks.) Resistance in Wheat
}

\author{
Anteneh Boydom ${ }^{1}$, Woubit Dawit ${ }^{2 *}$ and Getaneh W/Ab ${ }^{1}$
}

${ }^{1}$ Ambo Plant Protection Research Center, P.O. Box 32, Ambo, Ethiopia

${ }^{2}$ Department of Plant Sciences and Horticulture, Ambo University, P.O. Box 19, Ambo, Ethiopia

\begin{abstract}
The use of resistant cultivars is the most economical and effective method to control leaf rust of wheat caused by Puccinia triticina Eriks. Generally screening of wheat germplasm for resistance to rusts is carried out in the greenhouse and field conditions using seedling and adult plants. However, these screening trails are influenced by environmental factors and limit the number of races to be evaluated simultaneously. In the present study, a detached leaf assay was evaluated for screening of wheat germplasm resistance to leaf rust. As treatments, two senescence retardant chemicals (benzimidazole and kinetin) at different concentrations and combinations were added to $5 \%$ water-agar. The selected media was further validated in 20 wheat genotypes using three leaf rust races. The media containing $10 \mathrm{mg} / \mathrm{L}$ kinetin and $30 \mathrm{mg} / \mathrm{L}$ benzimidazole inoculated using an atomizer was the best in delaying the senescence and thereby increasing the sporulation. A positive correlation $(r=0.9)$ between the detached leaf assay and the whole seedling assay infection types was observed. The standard errors for detached leaf and whole seedling assays were 0.24 and 0.3 , respectively. The low standard errors further confirm the consistency of the disease response rating between the two assays. Generally this study revealed that the infection types were found to be similar both in detached leaf and whole seedlings assay. Therefore, detached leaf assay can be used to assess wheat genotypes against leaf rust.
\end{abstract}

Keywords: Leaf rust; Puccinia recondite; Detached leaf assay; Whole seedling assay; Wheat

\section{Introduction}

Puccinia triticina Eriks. is a wheat disease of major historical and economic importance worldwide. It is the most widespread of the three types of rusts causing significant yield loss over large geographical areas [1-4]. Yield losses due to leaf rust may be as high as 30 to $50 \%$ in years of severe infections [5]. The use of resistant wheat varieties is the most economical and effective method to control the disease. In Ethiopia, several resistant varieties have been released since 1974 but their resistance has broken down only a few years after release. This is attributed partly due to a lack of efficient screening techniques that targets all the pathogens prevailing in the area. Breeding for host resistance should be pre-emptive or anticipatory in approach so that cultivars to be developed should have adequate level of resistance against the prevailing pathotypes [6]. Wheat germplasm typically is evaluated for resistance to rusts in the greenhouse and the field using whole seedlings and adult plants $[7,8]$. However, these screening trails are often influenced by environmental factors that affect disease development [9]. In addition, field screening trails are seasonal and are generally conducted once per year. In both seedling and adult plant screening trails, infected plants cannot be completely isolated from other plants, limiting the number of pathogen races that can be evaluated simultaneously. The presence of multiple races is a constant problem for both cases especially when infection types (ITs) vary depending on the pathogen race or when a gene confers complete resistance, masking the partial effects of other genes In order to mitigate the problems or constraints of seedling and adult plant screening trails, a detached leaf assay were developed to evaluate virulence races of powdery mildew on barley (Blumeria graminis f. sp. hordei) [10]. In wheat, a detached leaf assay was developed to rapidly evaluate large numbers of accessions for resistance to Stagonospora nodorum (syn. Septoria nodorum) [11].

The assay was also used to assess crown rust resistance in oats, Puccinia coronata [12]. Similarly, a detached leaf assay was used to detect resistance to the fungal disease Phomopsis leaf blight, caused by Diaporthe toxica, in Lupinus albus [1]. Detached plant part screening assays are useful because they enable assessments to be made under highly controlled conditions, serve as rapid screening techniques that can be adopted by breeding programs and can assist in the understanding of host pathogen interactions [13-15]. A detached leaf assay conducted in vitro is only of benefit to the plant breeder if it correlates well to field responses [16]. Despite the importance of detached leaf technique for resistance screening of wheat germplasm against different foliar diseases, it is not well exploited in screening wheat germplasm against leaf rust. Therefore, the present study was conducted to identify the most optimum growth media for reduction of senescence and development of leaf rust disease symptoms and to further validate the technique by comparing the reactions of wheat genotypes to different leaf rust races using the detached leaf and whole seedling assays.

\section{Materials and Methods}

\section{Growth of seedlings and preparation of detached leaf segments}

Five seeds of the susceptible wheat cultivar Morocco were sown in $10 \mathrm{~cm}$ diameter clay pots and grown in a greenhouse under day light

*Corresponding author: Woubit Dawit, Department of Plant Sciences and Horticulture, Ambo University, P.O. Box 19, Ambo, Ethiopia, Fax: 0251-112362037; E-mail: woubit123@yahoo.com

Received March 19, 2013; Accepted May 20, 2013; Published May 25, 2013

Citation: Boydom A, Dawit W, Getaneh W/Ab (2013) Evaluation of Detached Leaf Assay for Assessing Leaf Rust (Puccinia triticina Eriks.) Resistance in Wheat. J Plant Pathol Microb 4: 176 doi:10.4172/2157-7471.1000176

Copyright: (c) 2013 Boydom A, et al. This is an open-access article distributed under the terms of the Creative Commons Attribution License, which permits unrestricted use, distribution, and reproduction in any medium, provided the original author and source are credited. 
condition at a temperature of $25^{\circ} \mathrm{C}$ and $80 \%$ relative humidity. The pots were filled with soil that contains a mixture of soil: sand: compost at the ratio of $2: 1: 1$. When the primary leaves of the seedlings were fully developed (seven days old), leaves were gently rubbed with clean moistened finger to remove waxy layer from the surface. Leaves were detached using scissors and surface-disinfected with a solution of $2 \%$ sodium hypochlorite. The leaves were subsequently rinsed in distilled water and dissected into segments. The distal portions of harvested leaves were removed while the middle segments of approximately $5 \mathrm{~cm}$ from each leaf was mounted adaxial side up on the surface of the wateragar which contained the different treatments [17].

\section{Preparation of solution}

Solutions for each treatment were prepared in 1 litre of sterilized distilled water. For this, the given amounts of senescence retardant chemicals in Table 1 were measured using a sensitive balance and diluted in 1 litre of sterilized distilled water. To thoroughly dissolve the chemicals, this solution was placed on a hot plate, adding magnetic stirrer, at $30^{\circ} \mathrm{C}$ for $2 \mathrm{hr}$. Since, the senescence retardant chemicals are light sensitive, the flask was plugged properly and covered with aluminum foil to protect from light and placed in refrigerator at $4^{\circ} \mathrm{C}$.

\section{Senescence retardant chemicals and preparation of solution}

Two senescence retardant chemical in different concentration and combinations were evaluated in the detached leaf assay (Table 1). 5\% water-agar media was prepared and autoclaved at $120^{\circ} \mathrm{C}$ for $30 \mathrm{~min}$ at $15 \mathrm{lb}$ pressure. The media was cooled to $60^{\circ} \mathrm{C}$ in a water bath and streptomycin sulphate $(5 \mathrm{mg} / \mathrm{lt})$ was added. The water-agar was prepared in $900 \mathrm{ml}$ of distilled water. This was adjusted to 1 litre by pouring 100 $\mathrm{ml}$ from each the solution of the plant senescence retardants which was previously prepared in 1 litre (Table 1 ). Approximately $30 \mathrm{ml}$ of media was dispensed into each petri-dish $(60 \times 15 \mathrm{~mm})$. Three replications (individual petri-dishes) were used and all replications were placed on the same shelf of the growth chamber to avoid temperature variation between shelves. Inoculated petri-dishes were covered, but left unsealed so that air exchange could occur, and placed in a dark growth chamber.

\section{Inoculation of detached leaves}

Spore suspensions of the leaf rust race PKKT were prepared by mixing $100 \mathrm{mg}$ of spores in $150 \mathrm{ml}$ of sterilized distilled water. Sterilized distilled water on its own was used as the control check (Table 1). The test was carried out in three replicates in a Complete Randomized Design (CRD). The susceptible cultivar, Morocco was used for this test. Two methods of inoculation namely spraying and brushing were used. Using an atomizer sprayer, $2-3 \mathrm{ml}$ of the suspension was sprayed to fully cover all the leaves in a Petri-dish. Using a paint brush leaves in Petri-dishes were inoculated by dipping the sterilized brush into $2-3 \mathrm{ml}$ of the spore suspension. For incubation, inoculated leaves in the Petri-dish were placed into a dark growth chamber at $15^{\circ} \mathrm{C}$ for $24 \mathrm{hr}$. After inoculation, plants were incubated in a dew chamber at a relatively $100 \%$ relative humidity and $15^{\circ} \mathrm{C}$ for $24 \mathrm{hr}$ and then the temperature was increased to $25^{\circ} \mathrm{C}$ and a $16 \mathrm{hr}$ photoperiod for the next 15 days. Evaluation of leaf rust development was carried out based on appearance of the disease symptoms and the rate of pustule development [18].

\section{Rust inoculation in cultivars and differentials wheat by detached leaf assay}

The better optimum media for sporulation of PKKT race in the Morocco cultivar (Table 1) was selected to evaluate the rust reaction in three cultivars and 16 differential wheat (Table 2). Additionally to

\begin{tabular}{|l|c|c|c|c|}
\hline \multirow{2}{*}{ Treatments } & \multicolumn{3}{|c|}{ Brush } & \multicolumn{2}{c|}{ Spray } \\
\cline { 2 - 5 } & \multicolumn{3}{|c|}{ Race PKKT } \\
\cline { 2 - 5 } & $\begin{array}{c}\text { Senescence } \\
\text { (\%) }\end{array}$ & IT & $\begin{array}{c}\text { Senescence } \\
\text { (\%) }\end{array}$ & IT \\
\hline Benzimidazole 30mg & 40 & 3 & 30 & $3^{+}$ \\
\hline Benzimidazole 60 mg & 30 & 3 & 25 & 3 \\
\hline Benzimidazole 100 mg & 20 & $3-$ & 20 & $3^{-}$ \\
\hline Kinetin 10 mg & 40 & 3 & 30 & 3 \\
\hline Kinetin10 mg+Benzimidazole 30 mg & 20 & $3^{+}$ & 15 & 4 \\
\hline Kinetin10 mg+Benzimidazole 60 mg & 20 & $3^{-}$ & 15 & $3-$ \\
\hline Kinetin10 mg+Benzimidazole 100 mg & 10 & $3^{-}$ & 5 & 2 \\
\hline Water agar & 100 & $2-$ & 100 & $2^{-}$ \\
\hline
\end{tabular}

*Standard errors for detached leaf and whole seedling assays were 0.24 and 0.3 , respectively. Infection type was recorded using 0-4 scale [18]

Table 1: Effect of senescence retardant chemicals in the percentage of leaf senescence and appearance of rust pustule (race PKKT of Puccinia triticina) by detached leaf assay using two inoculation methods in Morocco cultivar wheat.

PKKT, the races PDKT and NCTT were used to further authenticate the efficacy of the selected optimum media. These races were obtained from the collection made by Ambo Plant Protection Center, Ambo, Ethiopia in 2010. A similar method was applied as mentioned above for the preparation of detached leaves segments, inoculation, incubation and evaluation. The experiment was set in a Complete Randomized Design (CRD) with three replications, and each replication representing a petri-dish with inoculated detached leaves.

\section{Whole seedling assay}

The wheat cultivars as well as the leaf rust differentials were evaluated in the detached leaf test using the selected optimum growing media which were further tested for their reaction at seedling stage using the same leaf rust races under greenhouse conditions. Urediniospores of each race were mixed in sterilized distilled water at the ratio of $1 \mathrm{mg} / 1.5 \mathrm{ml}$ and used to inoculate twelve day old seedlings of the cultivars and the differentials. The inoculation was carried out using atomizer sprayer. To create dew required for rust development, before and after inoculation, the inoculated plants were sprayed with distilled water that contained $0.01 \%$ of Tween 80 . After inoculation the seedlings were incubated at $15-18^{\circ} \mathrm{C}$ for $24 \mathrm{hr}$ and then transferred to $20-25^{\circ} \mathrm{C}$, similar conditions as before inoculation for a couple of weeks, until they developed good symptoms. Disease symptoms were scored using infection types (IT) 1-4 according to Long and Kolmer [18] Data from each evaluation method was analyzed using the statistical procedures of SAS version 15.0 [19].

\section{Results}

Rust sporulation by detached leaves assay using different treatments

Leaf rust sporulation was observed on the detached leaves of the susceptible cultivar Morocco that were placed on $5 \%$ wateragar containing the different treatments of the senescence retardant chemicals after two weeks of culturing. There was no any contamination of the media by fungi that may have interfered with leaf rust growth and disease development (Figure 1).

The percent area of leaf senescence and the pathogen's growth varied with the concentrations and method of inoculations (Table 1). The media that contained $10 \mathrm{mg} /$ litre kinetin exhibited infection type to tested race, PKKT and per cent of leaf senescence of 3 and $30-40 \%$, respectively. Infection type of 3 or 3 -was observed for the concentration of benzimidazole that increased from 30 to $100 \mathrm{mg} /$ litre 


\begin{tabular}{|c|c|c|c|c|c|c|c|}
\hline \multicolumn{8}{|c|}{ Infection type to the tested races } \\
\hline \multirow[b]{2}{*}{ Differential line/Cultivars } & \multicolumn{4}{|c|}{ Detach leaf assay } & \multicolumn{3}{|c|}{ Whole seedling assay } \\
\hline & Lrgene & PKKT & NCTT & PDKT & PKKT & NCTT & PDKT \\
\hline TC*6/Centenatrio (RL6003) & Lr1 & 3 & 3 & 3 & 4 & 4 & 4 \\
\hline TC*6/Webster (RL6016) & Lr2a & 0 & 0 & 0 & 0 & 0 & 0 \\
\hline TC*6/Loros (RL6047) & $L r 2 c$ & 3 & 3 & 3 & 4 & 4 & $3^{+}$ \\
\hline TC*6/Democrat (RL6002) & $L r 3$ & 3 & 1 & 3 & 3 & 2 & $3^{+}$ \\
\hline Transfer/6*TC (RL6010) & $\operatorname{Lr} 9$ & 0 & 0 & 0 & 0 & 0 & 0 \\
\hline TC*6/Exchange (RL6005) & Lr16 & $3^{+}$ & $2^{+}$ & 2 & $3^{+}$ & 2 & 2 \\
\hline TC*6/Agent (RL6064) & $L r 24$ & 3 & 0 & 3 & 3 & 0 & 4 \\
\hline TC*6/ST-1-25 (RL6078) & Lr26 & 3 & 3 & 2 & $3^{-}$ & 4 & $1^{+}$ \\
\hline TC*6/Aniversario (RL6007) & Lr3ka & 2 & 3 & $2^{+}$ & 2 & 3 & $2^{+}$ \\
\hline Kussar (W976) & $L r 11$ & 3 & 3 & 3 & 4 & 4 & 4 \\
\hline Klein Lucero/6* TC (RL6008) & Lr17 & 4 & 3 & 3 & 3 & 4 & $3^{+}$ \\
\hline TC*6/ Terenz10 (RL6049) & Lr30 & 3 & 3 & 3 & 3 & 3 & 3 \\
\hline TC*6//CARINA (RL6051) & $L r B$ & $3^{+}$ & 3 & $3^{+}$ & 3 & 4 & $3^{+}$ \\
\hline TC*6/Exchange (RL6004) & Lr10 & $3^{+}$ & 3 & 3 & $3^{+}$ & $3+$ & 4 \\
\hline Selkirk/6* TC (RL6013) & Lr14a & 3 & 3 & 3 & 3 & 4 & $3^{+}$ \\
\hline TC*7/Africa 43 (RL6009) & Lr18 & 3 & 3 & 3 & $3^{+}$ & 4 & 4 \\
\hline Tussie (HAR 704) & - & 2 & 2 & 0 & 2 & 2 & 1 \\
\hline Foka & - & $1^{+}$ & 2 & 2 & $1^{+}$ & 1 & $1^{+}$ \\
\hline Kilinto & - & $2^{+}$ & $2^{+}$ & 2 & $2^{+}$ & 2 & 2 \\
\hline Morocco & No & $3^{+}$ & 4 & 3 & $3^{+}$ & $4^{+}$ & 4 \\
\hline
\end{tabular}

Infection type, recorded using 0-4 scale [18]

Table 2: Wheat cultivars and differentials with their resistance gene and infection types to races of Puccinia triticina observed in detached leaf and whole seedling assays.

(a)

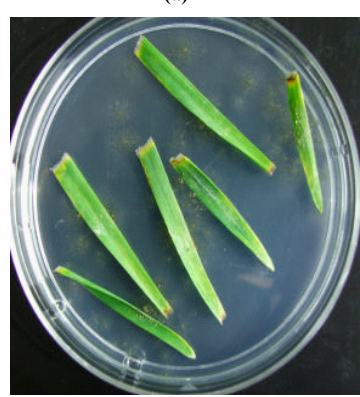

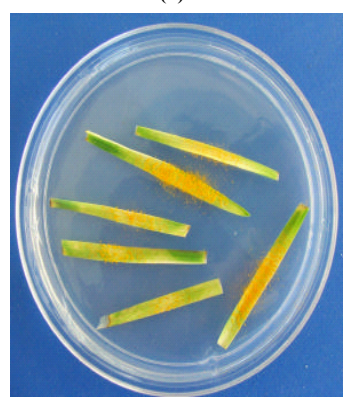

Figure 1: Infection types (IT) for leaf rust on the susceptible cultivar Morocco on kinetin $10 \mathrm{mg} /$ /itre and benzimidazole $30 \mathrm{mg} / \mathrm{litre}(\mathrm{a})$ and water-agar (b) to leaf rust race PKKT using detached leaf assay.

of water. The percentage of leaf senescence decreases from $30 \%$ to $20 \%$ and $40 \%$ to $20 \%$ for spray and brush, respectively on the concentration of benzimidazole increased.

The combined effect of the two chemicals (kinetin and benzimidazole) was effective in retarding leaf senescence as well as maintaining the growth of the fungus as compared to the effect of the chemicals individually. The infection types were found in the range of 3 to 4 which was grouped under high infection type in both methods of inoculation. Per cent leaf senescence varied from 15 to $5 \%$ for the concentration of benzimidazole that varied between $30-100 \mathrm{mg} /$ litre and combined with $10 \mathrm{mg} /$ litre kinetin. The control that contained wateragar without any senescent retardants showed distinctive difference either with individual or the combination of the two chemicals regarding leaf color. The detached leaves placed in water-agar medium completely lost their green color and turned yellow. Although there was decreased leaf senescence with increasing concentration of benzimidazole, it also inhibited leaf rust development on the susceptible cultivar. The best media for disease development proved to be the combination of 10

$\mathrm{mg} /$ litre kinetin and $30 \mathrm{mg} /$ litre benzimidazole inoculated by spraying using atomizer. In this treatment, the leaf retained $85 \%$ of its color and infection types of 4 , were recorded (Table 1 ).

\section{Rust sporulation in cultivars and differential wheat by detached leaves and whole seedling assays}

Table 2 shows the whole seedling diseases response of wheat differentials and cultivars after inoculating with the three different races of wheat leaf rust. The correlation between infection types of detached leaf assay and whole seedling assay was positive $(r=0.9)$. Standard errors for detached leaf and whole seedling assays were 0.24 and 0.3 , respectively.

\section{Discussion}

For development of a leaf rust resistant variety, a screening technique which is not influenced by factors that affect disease development and shows the true genetic resistance of the materials to be evaluated is paramount. Since wheat leaf rust is an obligate parasite, culturing in artificial growth media is difficult. In this study, two senescence retardant chemicals (benzimidazole and kinetin) at different concentrations and combinations were added in 5\% wateragar. Detached leaf assay resulted in successful infection of leaf segments by races of $P$. Triticina and the segments remained green for at least two weeks after inoculation. The detached leaves placed in wateragar medium completely lost their green color and turned yellow. The exhibited infection type was $2 / 2$, which may suggest that decreasing leaf senescence increases sporulation by maintaining the nutrition required for the pathogen.

The best media for disease development proved to be the combination of $10 \mathrm{mg} / \mathrm{lt}$ kinetin and $30 \mathrm{mg} / \mathrm{lt}$ benzimidazole. In this treatment the leaf retained $85 \%$ of its color and an infection type of 4 was recorded. Though the detached leaf assays were used extensively for other wheat diseases, there were different reports in the type and concentration of 
the senescence retardant chemicals. Loladze [20] reported that wateragar that contains $10 \mathrm{mg} /$ litre kinetin proved to be the fittest media for wheat stripe rust growth and development. Similarly Brown and Cook used $10 \mathrm{mg} / \mathrm{lt}$ kinetin as a senescence retardant for evaluation of prescreening resistance to Fusarium head blight in wheat [17]. In other study $100 \mathrm{mg} /$ litre benzimidazole to evaluate the resistance to Septoria tritici in wheat were used [21]. In a separate study, Felsenstein et al. [22] reported that, $35 \mathrm{mg} /$ litre benzimidazole used as detached leaf assay media for wheat leaf rust.

Disease ratings from the detached leaf assay and whole seedling assay were found to be similar confirming the effectiveness of the detached leaf assay applied here for assessing the diseases response of wheat differentials and cultivars to leaf rust. The correlation between infection types of detached leaf assay and whole seedling assay was positive $(r=0.9)$. Standard errors for detached leaf and whole seedling assays were 0.24 and 0.3 , respectively. Low standard errors for each evaluation method further confirm the consistency of the disease response ratings between the detached leaf and the whole seedling assays. Differences between the infection types of the detached leaf assay and the intact seedling assays were small, and it was due to the senescence of the detached leaves, which was observed as chlorotic and necrotic spots [20]. Since the pathogen is an obligate parasite, it cannot develop successfully on necrotic cells of detached leaves. Due to this phenomenon, it cannot produce large quantities of uredia and this condition leads to lower infection types [20]. Susceptible and resistant disease reactions were clearly visible on detached leaves in which a large amount of uredia and chlorosis were experienced in susceptible reactions however distinct flakes with no or little uredia was observed in resistant reactions. Generally, the results obtained from the experiment showed that detached leaf assay can be applied efficiently for resistance screening to wheat leaf rust.

\section{Acknowledgement}

The experiment was carried out in the Plant Protection Research Center (PPRC), Ambo, Ethiopia. Thus, the authors greatly acknowledge the technicians for their technical support. Professor T. Selvaraj, and Mr. Ebrahim Hamza, Department of Plant Sciences and Horticulture, College of Agriculture and Veterinary Sciences, Ambo University are also duly acknowledged for editing the manuscript.

\section{References}

1. Jackson EW, Obert DE, Chong J, Avant JB, Bonman JM (2008) Detached-leaf method for propagating Puccinia coronata and assessing crown rust resistance in oat. Plant Disease 92: 1400-1406.

2. Marasas CN, Smale M, Singh RP (2004) The economic Impact in Developing Countries of Leaf Rust Resistance Breeding in CIMMYT-Related Spring Bread Wheat. Economics Program Paper 04-01. Mexico, D.F. CIMMYT.

3. Samborski DJ (1985) Wheat leaf rust. In: The Cereal Rusts: Diseases distribution, epidemiology, and control. Academic Press, Orlando, FL, USA, 39-59.

4. Saari EE, Prescott JM (1985) World distribution in relation to economic losses In: The Cereal Rusts Volume II: Diseases, Distribution, Epidemiology and Control. London and Orlando: Academic Press, 259-298.

5. McIntosh RA, Wellings CR, Park RF (1995) Wheat rusts: An atlas of resistance genes. CSIROS Publications, Victoria, Australia.

6. McIntosh RA, Brown GN (1997) Anticipatory breeding for resistance to rust diseases in wheat. Annu Rev Phytopathol 35: 311-326.
7. Line RF (2002) Stripe rust of wheat and barley in North America: a retrospective historical review. Annu Rev Phytopathol 40: 75-118.

8. Line RF, Qayoum A (1992) Virulence, aggressiveness, evolution, and distribution of races of Puccinia striiformis (the cause of stripe rust of wheat) in North America, 1968-87. US Dep. Agric. Res. Serv. Tech. Bull. 1788.

9. Tollenaar $\mathrm{H}$, Houston $\mathrm{BR}$ (1966) In vitro germination of uredospores of Puccinia graminis and $P$. striiformis at low spore densities. Phytopathol 56: 1036-1039.

10. Brown JKM, Wolfe MS (1990) Structure and evolution of a population of Erysiphe graminis f. sp. hordei. Plant Pathol 39: 376-390.

11. Benedikz PW, Mappledoram CJ, Scott PR (1981) A laboratory technique for screening cereals for resistance to Septoria nodorum using detached seedling leaves. Trans Brit Myco Soc 77: 667-669.

12. Cowley RB, Luckett DJ, Harper JD, Ash GJ (2012) Development of a reliable and rapid detached leaf assay to detect resistance to the fungal disease phomopsis leaf blight caused by Diaporthe toxica, in Lupinus albus. Canadian $\mathrm{J}$ of Plant Pathol 34: 401-409.

13. Bradley CA, Henson RA, Porter PM, LeGare DG, Del Rio LE, et al. (2006) Response of canola cultivars to Sclerotinia sclerotiorum in controlled and field environments. Plant Disease 90: 215-219.

14. Ergon A, Tronsmo AM (2006) Components of pink snow mould resistance in winter wheat are expressed prior to cold hardening and in detached leaves. Journal of Phytopathology 154: 134-142.

15. Huang S, Vleeshouwers VGAA, Visser RGF, Jacobsen E (2005) An accurate in vitro assay for high-throughput disease testing of Phytophtora infestans in potato. Plant Dis 89: 1263-1267.

16. Irwin JA, Musial JM, Mackie JM, Basford KE (2003) Utility of cotyledon and detached leaf assays for assessing root reactions of lucerne to Phytophthora root rot caused by Phytoththora medicaginis. Australian Plant Pathological and Molecular Plant Pathol 40: 353-358

17. Browne RA, Cooke BM (2004) Development and evaluation of an in vitro detached leaf assay for pre-screening resistance to Fusarium head blight in wheat. Eur J of Plant Pathol 110: 91-102.

18. Long DL, Kolmer JA (1989) A North American system of nomenclature for Puccinia recondita f.sp. tritici. Phytopathol 79: 525-529.

19. SAS Institute Inc (1999) SAS/STAT ${ }^{\circledR}$ User's Guide, Version8, Cary, NC.

20. Loladze A (2006) Development of a detached leaf assay for stripe resistance screening. M.Sc. Thesis, Washington State University, Washington, USA.

21. Arraino LS, Brading PA, Brown JKM (2001) A detached seedling leaf technique to study resistance to Mycosphaerella graminicola (anamorph Septoria tritici) in wheat. Plant Pathol 50: 339-346.

22. Felsenstein FG, Park RF, Zeller FJ (1998) The use of detached seedling leaves of Triticum aestivum to Study Pathogenecity in Puccinia recondita f.sp. tritici. Journal of Phytopathology 146: 115-121. 